\title{
ECONOMIC FEASIBILITY OF PASSIVE STRATEGIES FOR ENERGY EFFICIENT ENVELOPES OF MASS-BUILT HOUSING IN HOT-DRY CLIMATE
}

\author{
K. D. REYES-BARAJAS, R. A. ROMERO-MORENO, A. LUNA-LEÓN, D. OLVERA-GARCÍA, \\ C. SOTELO-SALAS \& G. BOJÓRQUEZ-MORALES \\ Universidad Autónoma de Baja California, Mexico.
}

\begin{abstract}
The building and construction industry represents 36\% of the world's final energy use and 39\% of carbon emissions, while the residential sector is responsible for $22 \%$ of total energy consumption and $17 \%$ of carbon emissions. Therefore, energy consumption reduction measures are required by this sector, without affecting the living conditions of its occupants. In Baja California, Mexico, the more commonly used construction systems in mass-built housing are concrete block walls and cast in place insulated reinforced concrete roof deck. These systems negatively affect comfort conditions, especially in hot summer periods, and therefore increase energy consumption, particularly in areas with an hot-dry climate, such as Mexicali, Baja California. The objective of this article is to determine the cost-benefit of two passive design strategies applied in the housing envelope, which are thermal insulation and ventilated facade. A commercial model of mass-built housing was taken as a benchmark case. Building energy simulations were carried out with the Design Builder ${ }^{\circledR}$ program, whereby the performance of the house was evaluated without passive design strategies (benchmark case) and with applied strategies, that is, variations in thickness and position of the materials that make up the layers of the walls and roof. Additionally, the net present value (NPV) criterion was used to obtain the costs and benefits of the design strategies. The results show the differences in cooling demand, indoor operative temperature, and the total costs, in Mexican pesos, of the application of the strategies; the results show that there are significant energy savings, which contribute to reducing carbon emissions to the environment and provide economic savings for the user.
\end{abstract}

Keywords: economic feasibility, energy efficient envelope, hot-dry climate, mass-built housing, passive strategies.

\section{INTRODUCTION}

Elevated energy consumption in the hot arid climate of northern Mexico, including the states of Baja California, Chihuahua, Coahuila, Nuevo León, Sonora, Sinaloa, and Durango, is consistently attributed to the use of air conditioning (AC) units to ensure indoor thermal comfort [1], as well as the use of energy inefficient appliances [2,3]. AC dependency is exacerbated by the construction of thermally inadequate building envelopes, particularly in the housing sector, which consumes $18.8 \%$ of the national energy budget [4]. In this climate region, $48.1 \%$ of all residential buildings have at least one $\mathrm{AC}$ unit, which is used on average for 5-9 hours a day [5]; this represents $75 \%$ of all houses with AC in the country. Social housing is an important source of nation-wide energy consumption; it is the most prevalent housing sector in Mexico, with approximately 23 million houses, out of the 30 million overall [6].

Mass-built housing is generally designed without any climatic consideration $[7,8,9,10]$, and therefore, present long-lasting problems for the end user, which span from high indoor temperatures, well outside the thermal comfort range, to negative effects on indoor air quality, and even economic vulnerability, due to the user's need to retrofit their home to comply with adequate living standards.

Building energy use is affected by several factors, in addition to the environmental factors, such as the climatic conditions; the predominant elements of external heat gains are building 
geometry and the thermophysical properties of the building envelope [11]. Passive design strategies have been extensively implemented to reduce energy consumption and carbon emissions $[12,13,14]$. The reduction of external heat gain transfer by minimizing conductive heat flow in the building envelope is recommended in hot arid climates, where there is a significant difference in temperatures between the indoor and outdoor environments, as La Roche [15] points out. The most widely used strategies within this passive design measure include the use of insulation and implementation of a ventilated façade [16-19].

Ventilated facades bring about improvement in the buildings' thermal performance, especially in hot-dry climates, such as Mexicali, in northwestern Mexico [20-22]. This improvement is due to the air flow in the air cavity between the inner and outer layer of the ventilated facade, which reduces direct solar radiation heat gains and removes heat through natural and forced convection, therefore reducing energy demand for cooling [23-26]. While previous studies analyzed varying widths for the air cavity, whose width can vary depending on both the design and the desired energy performance, they did not compare the thermal performance of different materials or construction systems for the outer layer of the façade.

Additionally, insulation has proven its effectiveness at reducing heat gains, since adequate thermal insulation in the housing envelope in extreme climates can present considerable savings in energy consumption, with up to $20 \%$ of energy savings and 55\% reduction in cooling demand in desert climates [27], as well as improved thermal performance [28]. Even though Mexico's hot arid climatic region has the highest percentage of thermal insulation application in the country, it represents only $14.9 \%$ of residential buildings with some type of insulation [5], and only $22.5 \%$ of the houses have wall insulation, while almost $90 \%$ have roof insulation.

Therefore, this research focused on the evaluation of architectural solutions to reduce cooling demand and its related energy use. The thermal performance of a mass-built house model was analyzed to determine passive design strategies which minimize conductive heat flow through the building envelope, as well as the economic feasibility of the application of these strategies [29] through a cost-benefit analysis, which consists of a study of the return on investments made, with an environmental focus [30].

Taking these considerations into account, the present research evaluated the proposed passive design measures using the building energy simulation (BES) software Design Builder®. The simulation setup includes the climatic data of the studied city and the conditions and characteristics of the selected benchmark case. The simulation scenarios were analyzed with the application of the proposed measures, and favorable results were obtained in relation to energy consumption reduction and increased thermal comfort. In addition, a cost-benefit analysis of each of the studied cases was carried out using the net present value (NPV), which also yielded favorable results for the user.

\section{METHODS}

The research was carried out with a quantitative approach, which consisted of thermal performance evaluations whereby the behavior of the envelope was analyzed in the benchmark case (BC) and in the case studies with the proposed applications of passive design measures; in addition, the cost-benefit of all the evaluated cases was obtained.

\subsection{Climatic conditions}

Mexicali is located in Mexico's northwest, in the Sonoran Desert, where it shares an international border with Calexico in the American state of California. The city's climate is classified 
as BW(h')hw(x')(e')w', hot-dry extreme climate, according to the Köppen-Geiger classification modified by García (2004) for Mexican climates [31]. Mexicali has registered maximum temperatures of $45-54{ }^{\circ} \mathrm{C}$ in the summer period [20] and has an annual rainfall of $73.3 \mathrm{~mm}$ [32]. Mexicali and Calexico are contiguous cities closely built to the international border, so the weather file used in the building energy simulations is the CZ15RV2.epw from Calexico's Imperial Valley [33].

\subsection{Benchmark case}

In the selection of the benchmark case, a specific mass-built housing model was selected, with its main facade oriented south; the construction area occupies $41.24 \mathrm{~m}^{2}$ on a $120.05 \mathrm{~m}^{2}$ plot. The house has two bedrooms, a bathroom, a living room/dining room, and kitchen as shown in Fig. 1. The construction system is the most commonly used in the city; the walls are made of $0.12 \times 0.20 \times 0.40 \mathrm{~m}$ concrete masonry unit (CMU) blocks, with hollow cells cast with concrete, $f^{\prime}{ }_{\mathrm{c}}=140 \mathrm{~kg} / \mathrm{cm}^{2}$, at every $0.61 \mathrm{~m}$. The roof is a cast in place insulated reinforced concrete roof deck of $0.17 \mathrm{~m}$ in thickness, with concrete $f^{\prime}{ }_{\mathrm{c}}=200 \mathrm{~kg} / \mathrm{cm}^{2}$ and reinforcing steel \#3 $(0.0071 \mathrm{~m})$, covered with fiberglass reinforcing mesh and two layers of smooth texture plaster, finished with elastomeric paint.

\subsection{Case studies with applied passive design strategies}

The investigation considers a benchmark case (BC) and 12 case studies, for which the BC envelope was retrofitted with the application of passive design strategies. The case studies were divided into three groups. Group A, where thermal insulation was used with $0.0254 \mathrm{~m}$ $(1 ")$ of expanded polystyrene (EPS) applied in each of the orientations of the vertical envelope. Group B was evaluated with an opaque ventilated façade, where the air cavity varied in width, from $0.10 \mathrm{~m}$ to $0.35 \mathrm{~m}$, only applied in the southern orientation, due to its greater
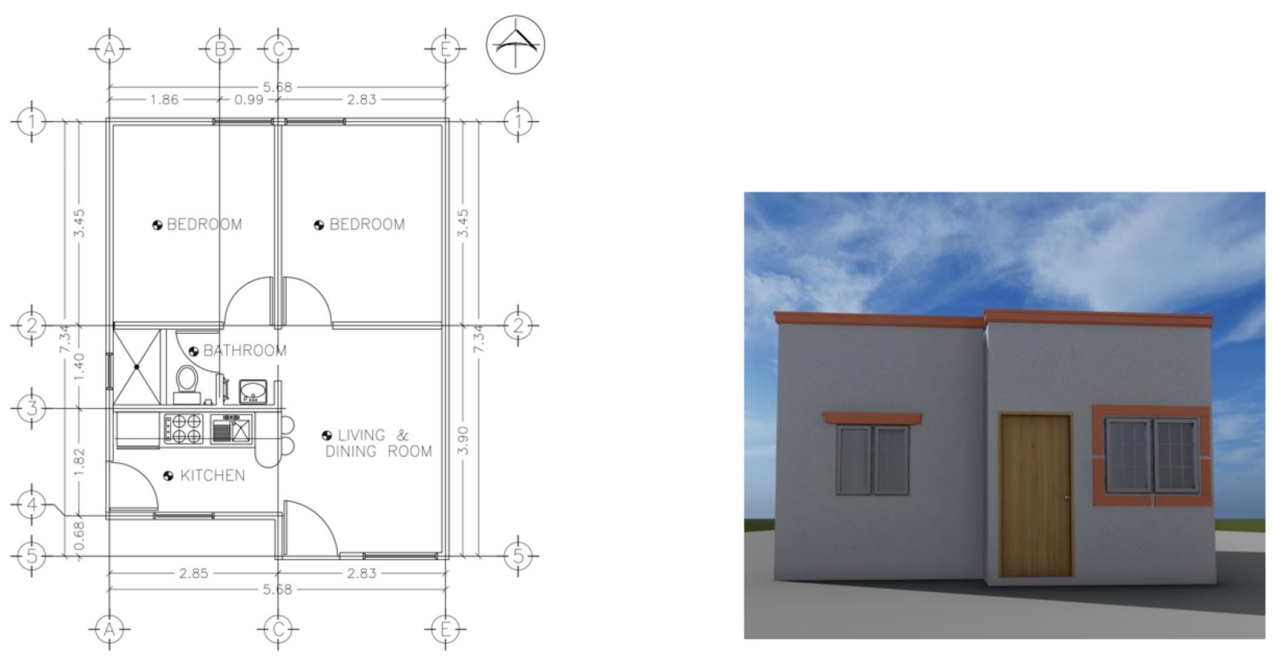

Figure 1: Benchmark case (BC) (source: RUBA construction plans, 2011). 
exposition to direct solar heat gains (east and west orientations are larger in area but shaded by adjacent houses). The outer layer of the ventilated facade is a lightweight steel framed construction system with $1.22 \mathrm{~m}\left(4^{\prime}\right)$ by $2.43 \mathrm{~m}\left(8^{\prime}\right)$ gypsum board drywall $0.0127 \mathrm{~m}\left(1 / 2^{\prime \prime}\right)$ on the interior face of the wall, a rectangular hollow section structure (RHS) of $0.0762 \mathrm{~m} \mathrm{(3")}$ at every $0.60 \mathrm{~m}\left(24^{\prime \prime}\right)$ in both directions, fiberglass thermal insulation, and exterior finish of $0.0127 \mathrm{~m}$ fiber cement board $\left(1 / 2^{\prime \prime}\right)$ (Durock USG®). Ventilation grills were added for natural convection inside the air cavity of the ventilated facade. Finally, group $\mathrm{C}$ was simulated with the combination of strategies $\mathrm{A}$ and $\mathrm{B}$, one case $(\mathrm{C} 1)$ with the configuration which presented the best performance in group B and the least promising of group A, and the second case (C2), which presented the largest savings in both groups. All case studies are listed in Table 1.

\subsection{Building energy simulation}

Design Builder ${ }^{\circledR}$ version 5.4.0.021 was used; for the thermal performance evaluation. The location of the city of Mexicali was selected, situated at a latitude $32^{\circ} 39^{\prime} 54^{\prime \prime} \mathrm{N}$, longitude $115^{\circ} 27^{\prime} 21^{\prime \prime} \mathrm{W}$, and an above sea level height of 4 meters [32]. To represent climate conditions, the Energy Plus Weather file (EPW) of the California climate zone 15 was used. Internal heat loads were specified through energy use schedules, for the people, equipment, and lighting indicated in Table 2 . A temperature set point of $24-25^{\circ} \mathrm{C}$ was considered [34].

Simulations were performed for the summer period of the studied city (May-October), materials and construction systems as listed in Table 2. It is important to note that when indoor thermal comfort was evaluated, all the case studies were simulated with natural ventilation and only the $\mathrm{BC}$ was evaluated with air conditioning and with natural ventilation; this allows the comparison of the $\mathrm{BC}$ and the studied cases in natural conditions, and thus can demonstrate the impact of each applied strategy to the indoor thermal conditions of the building.

Therefore, thermal performance and comfort conditions results were obtained, depending on the cooling load (zone sensible cooling), gains per wall $\left(\mathrm{kW} / \mathrm{m}^{2}\right)$, and comfort based on the predicted mean vote (PMV) model. For the analysis of these data, especially those of thermal comfort, the data obtained by building energy modeling had to be processed in a spreadsheet [35], in order to present data on the scale established by the PMV model in the ISO 7730 standard [36] (Table 3).

Table 1: Case studies with passive design strategies.

\section{Benchmark case (BC)}

Design strategy A: Benchmark case with $0.0254 \mathrm{~m}\left(1^{\prime \prime}\right)$ expanded polystyrene insulation

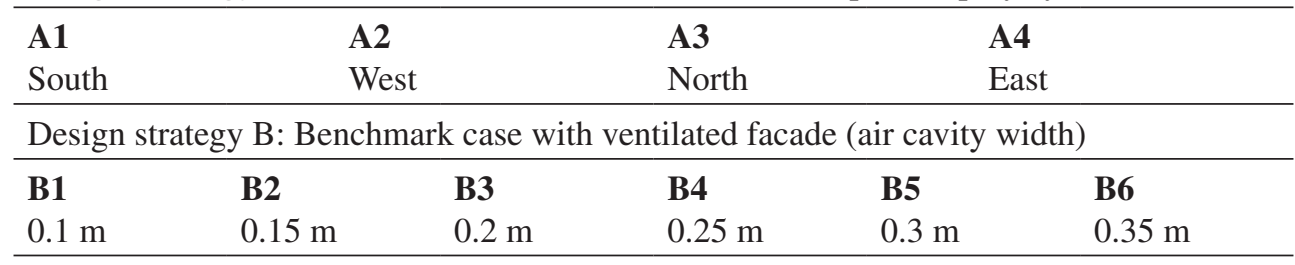

Design strategy C: Benchmark case with combination of group A and group B strategies

C1

(A1 and B6)
C2

(A4 and B6) 
Table 2: Simulation setup.

\begin{tabular}{|c|c|c|c|}
\hline Parameter & Description & Value & Units \\
\hline \multirow[t]{4}{*}{ Climate data } & City & $\begin{array}{l}\text { Mexicali, } \\
\text { Mexico }\end{array}$ & \\
\hline & Location & $\begin{array}{l}32.8^{\circ} \mathrm{N} \\
-115.67^{\circ} \mathrm{W}\end{array}$ & \\
\hline & Weather file & $\begin{array}{l}\text { CZ15RV2. } \\
\text { epw }\end{array}$ & \\
\hline & Time zone & $\begin{array}{l}\text { GMT -08:00 } \\
\text { Tijuana }\end{array}$ & \\
\hline \multirow[t]{2}{*}{ Building } & Construction area & 41.24 & $\mathrm{~m}^{2}$ \\
\hline & Main façade & South & \\
\hline \multirow[t]{4}{*}{$\begin{array}{l}\text { Construction } \\
\text { system - U value }\end{array}$} & $\begin{array}{l}\text { BC: concrete masonry unit blocks, cast } \\
\text { cores, } 0.12 \mathrm{~m}\end{array}$ & 2.932 & $\begin{array}{l}\mathrm{W} / \mathrm{m}^{2} \\
{ }^{\circ} \mathrm{C}\end{array}$ \\
\hline & $\begin{array}{l}\text { BC: insulated reinforced concrete roof } \\
\text { deck, } 0.17 \mathrm{~m}\end{array}$ & 0.860 & $\begin{array}{l}\mathrm{W} / \mathrm{m}^{2} \\
{ }^{\circ} \mathrm{C}\end{array}$ \\
\hline & $\begin{array}{l}\text { Design strategy A: Concrete masonry unit } \\
\text { blocks, cast cores, } 0.12 \mathrm{~m} \text { with a layer of } \\
\text { expanded polystyrene, } 0.0254 \mathrm{~m}\end{array}$ & 0.988 & $\begin{array}{l}\mathrm{W} / \mathrm{m}^{2} \\
{ }^{\circ} \mathrm{C}\end{array}$ \\
\hline & $\begin{array}{l}\text { Design strategy B: Fiber cement board } \\
\text { wall } 0.12 \mathrm{~m} \text { with fiberglass insulation and } \\
\text { ventilated façade (with varying air cavity } \\
\text { thickness) }\end{array}$ & 0.424 & $\begin{array}{l}\mathrm{W} / \mathrm{m}^{2} \\
{ }^{\circ} \mathrm{C}\end{array}$ \\
\hline \multirow[t]{3}{*}{ Internal loads } & $\begin{array}{l}\text { People: } \\
\text { (4) users }\end{array}$ & 4,027 & $\mathrm{~W}$ \\
\hline & $\begin{array}{l}\text { Equipment: } \\
\text { (2) Stove burner } \\
\text { (1) Microwave } \\
\text { (1) Coffee maker } \\
\text { (1) Blender } \\
\text { (3) Television } \\
\text { (1) Wireless telephone } \\
\text { (5) Cellular phone charger } \\
\text { (1) Modem } \\
\text { (1) Laptop } \\
\text { (1) Bathroom exhaust fan } \\
\text { (1) Hair dryer } \\
\text { (1) Electric shaver }\end{array}$ & 19,742 & W \\
\hline & $\begin{array}{l}\text { Lighting } \\
\text { (5) } 100 \mathrm{~W} \text { incandescent light bulb } \\
\text { (2) } 60 \mathrm{~W} \text { incandescent light bulb }\end{array}$ & 2,550 & $\mathrm{~W}$ \\
\hline Cooling system & $\begin{array}{l}\text { (3) Mini split } 3.28 \text { COP } \\
\text { Turned on, } 24 \text { hours, } 7 \text { days a week }\end{array}$ & $\begin{array}{l}18,736.7 \\
24-25^{\circ} \mathrm{C} \\
\text { set point }\end{array}$ & $\mathrm{W}$ \\
\hline
\end{tabular}


Table 3: Thermal comfort scale (source: ISO 7730, 2020).

\begin{tabular}{llll}
\hline Model & Standard & \multicolumn{2}{c}{ Comfort scale - thermal sensation } \\
\hline & & -3 & Very cold \\
& -3 to -2 & Cold \\
& -2 to -1 & Cool \\
& -1 to -0.5 & Slightly cool \\
& & -0.5 to 0.5 & Neutral (comfortable) \\
PMV & 0.5 to 1 & Slightly warm \\
& ISO-7730 & to 2 & Warm \\
& & 2 to 3 & Hot \\
& & & Very hot \\
\hline
\end{tabular}

\subsection{Cost-benefit analysis}

The cost-benefit analysis of each case study was carried out. For this, it was necessary to know the total cost of the initial investment that the user would have to make in each of the proposed strategies, the cost of minor and major maintenance (established at two and a half and five years, respectively), the annual rate of inflation [37], the costs from the consumption of electricity [38], and the useful life span of the house established at 30 years (Table 4). To do this, the following net present value (NPV) formula was used:

$$
\mathrm{NPV}=-P+\frac{F N E}{(1+i)^{n}}+\frac{F N E}{(1+i)^{n}}+\ldots
$$

Table 4: Economic evaluation data.

\section{Cost (Mexican currency)}

\section{Constructive system}

Wall

\section{Annual rate of inflation}

\section{Initial investment}

Maintenance

\begin{tabular}{lllllll}
$\begin{array}{l}\text { Orienta- } \\
\text { tion }\end{array}$ & $\begin{array}{l}\text { Area } \\
\left(\mathbf{m}^{\mathbf{2}}\right)\end{array}$ & $\begin{array}{l}\text { Expanded } \\
\text { polysty- } \\
\text { rene }\end{array}$ & $\begin{array}{l}\text { Fiber ce- } \\
\text { ment board }\end{array}$ & Major $^{\mathbf{3}}$ & Minor $^{\mathbf{4}}$ & \\
\cline { 1 - 5 } North & 15.47 & $3,545.56$ & $9,220.12$ & $1,856.40$ & $1,284.01$ & $4 \%$ \\
South & 14.02 & $3,213.24$ & $8,355.92$ & $1,682.40$ & $1,163.66$ & \\
East & 22.04 & $5,051.34$ & $13,135.84$ & $2,644.80$ & $1,829.32$ & \\
West & 20.25 & $4,641.09$ & $12,069.00$ & $2,430.00$ & $1,680.75$ & \\
\hline
\end{tabular}

${ }^{1}$ The cost of expanded polystyrene over existing wall is $\$ 229.19 / \mathrm{m}^{2}$.

${ }^{2}$ The cost of gypsum board drywall with fiberglass insulation is $\$ 596.00 / \mathrm{m}^{2}$.

${ }^{3}$ The cost of plaster, molding replacement, and crack repairs is $\$ 120.00 / \mathrm{m}^{2}$.

${ }^{4}$ The cost of wall painting with detailing is $\$ 83.00 / \mathrm{m}^{2}$. 
where $P$ corresponds to the initial investment, $F N E$ corresponds to the net cash flow of year $n$ (net profit after taxes for the year), and $i$ is the annual inflation rate [39].

The cost-benefit study of passive strategies was carried out, with the purpose of this research being to determine if one or more of the proposed strategies is convenient to the user considering three aspects: thermal, i.e. comfort; energetic, i.e. energy savings; and economic, namely, cost of investment of the application of the passive design strategies in the house.

\section{RESULTS}

The results are presented in three sections: energy performance, thermal comfort, and cost-benefit. Energy performance results include heat gains $(\mathrm{kWh})$ and zone sensible cooling or cooling loads $(\mathrm{kWh})$; thermal comfort results comprise percentages based on the comfort hours obtained in the summer period, and cost-benefit includes expenses (in Mexican currency).

\subsection{Energy performance}

Table 5 shows the results in kWh of the simulations of strategy A [40]; this shows that the southern-oriented wall receives higher heat gains than the rest of the vertical envelope, with an excess of $600 \mathrm{kWh}$ per square meter, and thus merits the application of strategy B to the southern wall. Likewise, it is observed that the $B C$ had a total gain for walls close to $10,000 \mathrm{kWh}$ and also that in the case studies, the critical one is the A1 with 1,272 $\mathrm{kWh}$ less than in the BC.

Table 6 shows the results of heat gains per wall for the rest of the studied cases; it is observed that the option that resulted in the lowest gains is $\mathrm{C} 2$, since its gains, at more than $5,000 \mathrm{kWh}$, are by $46.16 \%$ less compared to BC.

In Fig. 2, a comparison of all case studies is presented [40].

The results of Table 7 show that the best case is also C2, with more than 3,000 kWh saved in energy removal compared to the BC. The case study that presented the least amount of savings was $\mathrm{C} 1$ with $795.37 \mathrm{kWh}$ less compared to the BC.

\subsection{Thermal comfort}

Thermal comfort evaluation in the BC was initially modeled with the HVAC system turned on, and therefore, the results indicated $100 \%$ comfort conditions, so it was decided to model the $\mathrm{BC}$ with natural ventilation, to establish a comparable baseline for the effect of the applied passive strategies. In the $\mathrm{BC}$, with natural ventilation conditions, less than 800 hours of comfort were obtained, and in the case studies with the application of the design strategies, results showed more than 950 hours of thermal comfort. However, the worst case is the A3 with 985

Table 5: Design strategy A heat gains: Thermal insulation (source: Reyes-Barajas et al. 2020).

\begin{tabular}{llll}
\hline Case & Heat gains per wall $(\mathbf{k W h})$ & $\mathbf{~ m}^{\mathbf{2}}$ & $\begin{array}{l}\text { Heat gain } / \mathbf{m}^{\mathbf{2}} \text { (wall surface } \\
\text { area) }\end{array}$ \\
\hline CB & $9,988.56$ & 72.15 & - \\
A1 & $8,716.27$ & 14.02 & 621.52 \\
A2 & $7,889.90$ & 20.25 & 389.57 \\
A3 & $8,908.25$ & 15.47 & 575.84 \\
A4 & $7,444.92$ & 22.04 & 332.30 \\
\hline
\end{tabular}


Table 6: Design strategy B heat gains: air cavity; design strategy $\mathrm{C}$ heat gains: combination $\mathrm{A}$ and $\mathrm{B}$.

\begin{tabular}{ll}
\hline Case & Heat gains $(\mathbf{k W h})$ \\
\hline B1 & $8,025.68$ \\
B2 & $8,001.74$ \\
B3 & $7,977.8$ \\
B4 & $7,956.3$ \\
B5 & $7,934.36$ \\
B6 & $7,911.76$ \\
C1 & $7,927.10$ \\
C2 & $5,371.79$ \\
\hline
\end{tabular}

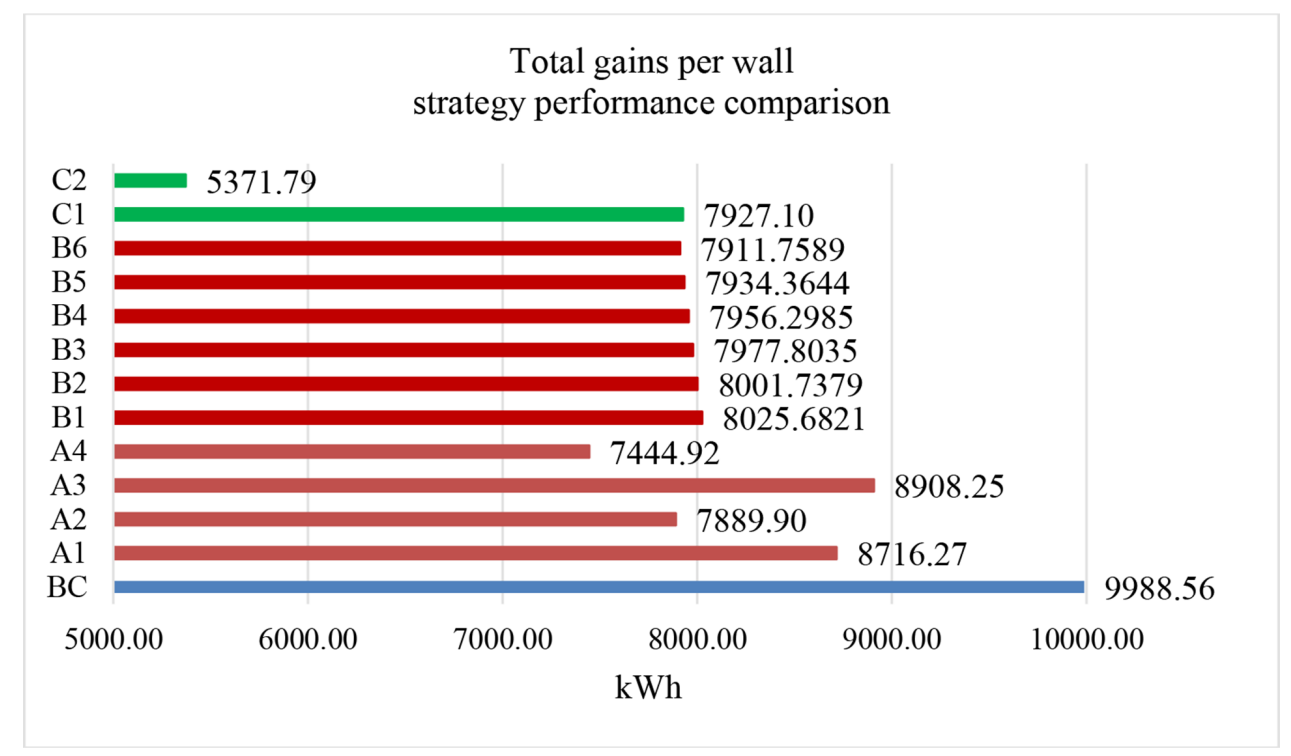

Figure 2: Case studies heat gains per wall.

comfort hours more than the $\mathrm{BC}$, while the case with the most comfort hours is $\mathrm{C} 2$ with more than 1,300 hours compared to the BC (Table 8).

\subsection{Economic evaluation: cost-benefit}

It is shown that with all the proposed design strategies, there are savings in energy consumption compared to the $\mathrm{BC}$, so that any strategy applied to the house is considered favorable. Additionally, the economic evaluation, with the use of the NPV formula for each case study, confirmed that all cases presented both energetic and economic savings. The amount saved depends on the case study applied, for example, if case $\mathrm{C} 1$ is used, the saving with respect to the $\mathrm{BC}$ is more than $\$ 14,000$ Mexican pesos (\$696.62 USD); on the other hand, if the case A4 is applied, savings are four times higher than with C1 (Table 9). 
Table 7: Case studies cooling load.

\begin{tabular}{ll}
\hline Case & Cooling load $(\mathbf{k W h})$ \\
\hline BC & $-17,337.63$ \\
A1 & $-16,113.77$ \\
A2 & $-15,339.30$ \\
A3 & $-16,285.66$ \\
A4 & $-14,870.49$ \\
B1 & $-16,007.1$ \\
B2 & $-16,411.7$ \\
B3 & $-16,480.3$ \\
B4 & $-16,483.8$ \\
B5 & $-16,496.1$ \\
B6 & $-16,502.7$ \\
C1 & $-16,542.26$ \\
C2 & $-14,005.41$ \\
\hline
\end{tabular}

Table 8: Case studies thermal comfort.

\begin{tabular}{|c|c|c|c|}
\hline Case & Comfort hours in summer & Total hours in summer period & Percentage \\
\hline $\mathrm{BC}$ & 786 & & 17.8 \\
\hline A1 & 995 & & 22.5 \\
\hline $\mathrm{A} 2$ & 1,035 & & 23.4 \\
\hline A3 & 985 & & 22.3 \\
\hline A4 & 1,032 & & 23.4 \\
\hline B1 & 1,027 & & 23.3 \\
\hline B2 & 999 & $4,416 \mathrm{~h}$ & 22.6 \\
\hline B3 & 1,309 & & 29.6 \\
\hline B4 & 1,319 & & 29.9 \\
\hline B5 & 1,323 & & 30.0 \\
\hline B6 & 1,333 & & 30.2 \\
\hline $\mathrm{C} 1$ & 1,346 & & 30.5 \\
\hline $\mathrm{C} 2$ & 1,387 & & 31.4 \\
\hline
\end{tabular}

Thus, in Fig. 3, the total costs of the BC and the case studies are shown; it is observed that $\mathrm{BC}$, appropriate maintenance for the useful life span of the house, the cost would be $\$ 245,898.02$ Mexican pesos $(\$ 12,235.56$ USD). It is also observed that in the cost-benefit analysis, the option that represents the greatest economic savings is the A4 case, while the one with the lowest savings is $\mathrm{C} 1$. 
Table 9: Economic savings in case studies.

\begin{tabular}{ll}
\hline Case & Present net value $\mathbf{( \$ - M X N )}$ \\
\hline A1 & $35,324.58$ \\
A2 & $49,292.85$ \\
A3 & $29,552.53$ \\
A4 & $61,496.02$ \\
B1 & $32,319.70$ \\
B2 & $21,356.46$ \\
B3 & $19,535.58$ \\
B4 & $19,355.58$ \\
B5 & $18,957.07$ \\
B6 & $18,738.94$ \\
C1 & $14,539.39$ \\
C2 & $53,139.53$ \\
\hline
\end{tabular}

\section{Total cost}

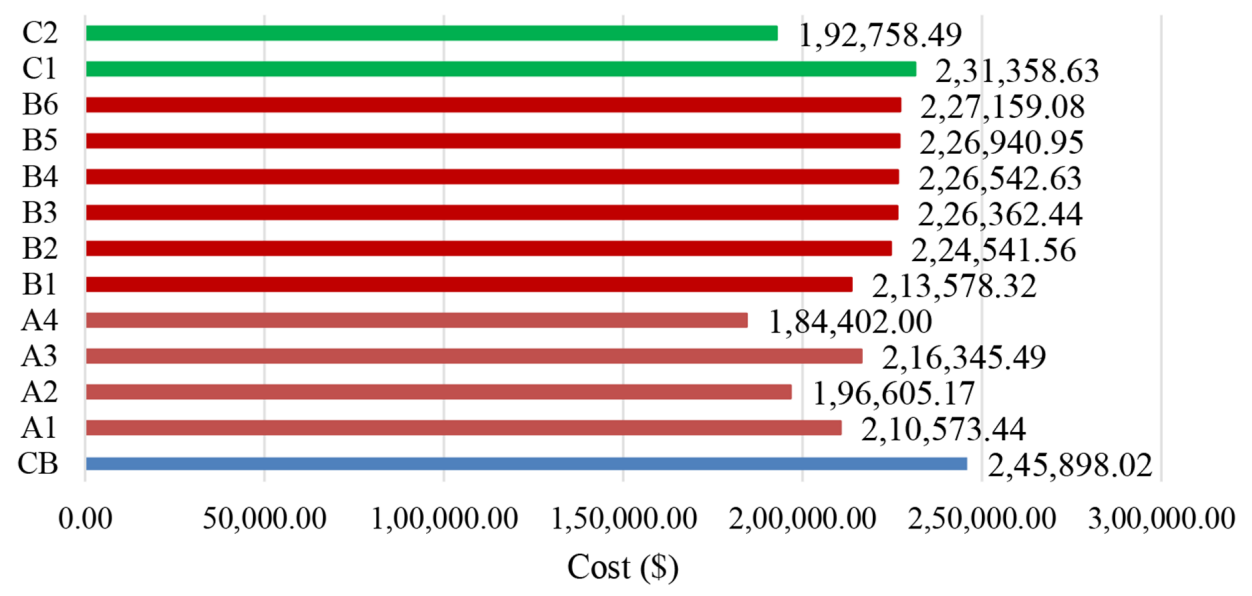

Figure 3: Total cost of design strategy implementation.

\section{DISCUSSION}

Given the climatic conditions of Mexicali during the summer period, where temperatures reach over $40^{\circ} \mathrm{C}$, and the current construction systems, which do not allow comfortable conditions inside the house unless an air conditioning unit is used, it is feasible to increase the energy efficiency of an existing house with the integration of passive design strategies in the envelope according to the geographical orientation. For this to be effective, it is necessary to balance the decrease in heat gain with the increase in thermal comfort conditions for the user, within a framework of economic viability. 
Energy efficiency regulations promote the use of thermal insulation to reduce energy consumption when using a mechanical air conditioning system. The use of a second design strategy, such as the ventilated facade, will improve the thermal performance of the housing envelope further.

\section{CONCLUSIONS}

For the selection of passive strategies, it is necessary to use the criteria of thermal performance (heat gain), energy performance (energy to be withdrawn), thermal comfort conditions (hours), and economic viability (cost-benefit) in a balanced and joint manner.

According to the heat gain per square meter with thermal insulation (strategy A), the south orientation is the one with the highest heat gain, $60 \%$ more than that of the west and $87 \%$ more than that of the east. This shows that measures are required to decrease heat gain in the south orientation.

The implementation of an opaque ventilated façade with an air cavity (strategy B) in the south orientation turned out to be adequate due to the location of the house on the lot. Each increase in air cavity width by $0.05 \mathrm{~m}$ decreases heat gain by around $22-24 \mathrm{kWh}$; increasing the width up to $0.35 \mathrm{~m}$ was key to achieving a balance between the factors analyzed for the selection of design strategies.

It is observed that there is a greater number of hours of comfort with ventilated facade techniques than with thermal insulation; the number of hours of thermal comfort is directly increased by increasing the width of the air cavity; and that the increments from a width of $0.20 \mathrm{~m}$ to $0.35 \mathrm{~m}$ are not significant.

Regarding the cost-benefit, the best option was thermal insulation in eastern orientation (strategy A4); however, from the perspective of energy consumption and comfort, it does not provide significant improvement, while the A4 strategy with the addition of the air cavity of $0.35 \mathrm{~m}$ costs only $\$ 8,300$ Mexican pesos more than A4. Hence, there is no significant economic difference, but there is considerable benefit in energy consumption and comfort.

Consequently, it was determined that the option with the greatest benefits is the combination of the ventilated façade with an air cavity width of $0.35 \mathrm{~m}$ (south wall) and the thermal insulation in the east wall (strategy C2). With the application of this design strategy, it was possible to reduce heat gains per wall by more than $4,000 \mathrm{kWh}$ and the cooling load by just over 3,000 kWh, compared to BC. Likewise, it is the best case for comfort, since it managed to increase thermal comfort by $13.6 \%$ inside the house.

Finally, it is clearly demonstrated that the implementation of passive design measures, such as thermal insulation and opaque ventilated façades, has a favorable impact in hot climates and in turn benefits the user, since these strategies improve the thermal indoor environment, which causes electrical energy savings and therefore economic savings.

\section{ACKNOWLEDGMENTS}

The authors thank the Autonomous University of Baja California and the Master and Doctorate program in Architecture, Urbanism and Design (MyDAUD) for the support provided to carry out this study, the National Council of Science and Technology (CONACyT) for the scholarship provided for the completion of master's degree studies, as well as the RUBA construction company.

\section{REFERENCES}

[1] Luna, A., Diseño y Evaluación de una Vivienda Energéticamente Sustentable para Climas Desérticos, Unpublished Ph.D. thesis, Universidad Autónoma de Baja California, 
2008, http://ceener.mxl.uabc.mx/diseno-y-evaluacion-de-vivienda-energeticamentesustentable-para-climas-deserticos/\#. Accessed on: 03 Jun. 2020.

[2] Boeri, A., Gianfrate, V., \& Longo, D., Green buildings and design for adaptation: Strategies for renovation of the built environment. International Journal of Energy Production and Management, 1(2), pp. 172-191, 2016. https://doi.org/10.2495/EQV1-N2-172-191

[3] Yathreb, S., Analysis of a residential building energy consumption as "base model" in Tripoli, Lebanon. International Journal of Energy Production and Management, 1(4), pp. 359-370, 2016. https://doi.org/10.2495/EQ-V1-N4-359-370

[4] Balance Nacional de Energía. Ciudad de México: Secretaría de Energía. Secretaría de Energía, 2015, https://www.gob.mx/cms/uploads/attachment/file/248570/Balance_ Nacional_de_Energ_a_2015_2_.pdf . Accessed on: 25 March. 2020.

[5] Instituto Nacional de Estadística y Geografía, Encuesta Nacional Sobre Consumo De Energéticos En Viviendas Particulares, http://www.beta.inegi.org.mx/contenidos/saladeprensa/boletines/2018/EstSociodemo/ENCEVI2018.pdf. Accessed on: 27 March. 2020.

[6] González Osorio, L.M. \& y Beele, A., Estudio de Caracterización del uso de Aire Acondicionado en Vivienda de Interés Social. México: CONUEE / GIZ. (2016). https://www. gob.mx/cms/uploads/attachment/file/164221/Conuee_2016_Estudio_Caracterizaci_n_ Uso_Aire_Acondicionado_en_Vivienda.pdf. Accessed on: 03 Jun. 2021.

[7] Gutiérrez, T., Romero, R. \& y Sotelo, C., Thermal energy impact of bioclimatic strategies applied to low-income housing in a hot dry climate. Energy Procedia, 57, pp. 1743-1752, 2014.

[8] Ochoa, J., Marincic, I., Alpuche, M.G., González, I., Barrios, G., Barajas, L.M. \& y Gómez, A., Thermal comfort and energy performance of social housing in hot-dry climates. Passive Low Energy Architecture Conference 2012, pp. 25-30, 2012.

[9] Romero-Pérez, C.K., Rodríguez-Muñoz, N.A., Alpuche-Cruz, M.G. \& y MartínDomínguez, I.R., Preliminary study of the condition of social housing in the city of Durango, México. Procedia Engineering, 134, pp. 29-39, 2017.

[10] Becerra-Santacruz, H. \& y Lawrence, R., Evaluation of the thermal performance of an industrialised housing construction system in a warm-temperate climate: Morelia, Mexico. Building and Environment, 107, pp. 135-153, 2016.

[11] Jannat, N., Hussien, A., Abdullah, B. \& Cotgrave, A., A comparative simulation study of the thermal performances of the building envelope wall materials in the tropics. Sustainability, 12(4892), pp. 1-26, 2020. doi:10.3390/su12124892

[12] Irulegi, O., Torres, L., Serra, A., Mendizabal, I. \& Hernandez, R., The Ekihouse: An energy self-sufficient house based on passive design strategies. Energy and Buildings, 83, pp. 57-69, 2014. http://dx.doi.org/10.1016/j.enbuild.2014.03.077

[13] Srivastav, S. \& Jones, P.J., Use of traditional passive strategies to reduce the energy use and carbon emissions in modern dwellings. International Journal of Low-Carbon Technologies, 4, pp. 141-149, 2009. doi:10.1093/ijlct/ctp021

[14] Wang, F., Yang, W.J. \& Sun, W.F., Heat transfer and energy consumption of passive house in severely cold area: simulation analyses. Energies, 13(626), pp. 1-19, 2020. doi:10.3390/en13030626

[15] La Roche, P., Carbon-Neutral Architectural Design, CRC Press: Boca Raton, pp. 290292, 2017. https://doi.org/10.5040/9781472596178-bed-a068 
[16] Belkacem, N., Loukarfi, L., Missoum, M., Naji, H., Khelil, A. \& Braikia, M., Assessment of energy and environmental performances of a bioclimatic dwelling in Algeria's North. Building Services Engineering Research and Technology, 38(1), pp. 64-88, 2016. https://doi.org/https://doi.org/10.1177/0143624416669554

[17] Bhamare, D.K., Rathod, M.K. \& Jyotirmay, B., Evaluation of cooling potential of passive strategies using bioclimatic approach for different Indian climatic zones. Journal of Building Engineering, 31, p. 101356, 2020. https://doi.org/https://doi.org/10.1016/j. jobe.2020.101356.

[18] Manzano-Agugliaro, F., Montoya, F.G., Sabio-Ortega, A. \& García-Cruz, A., Review of bioclimatic architecture strategies for achieving thermal comfort. Renewable and Sustainable Energy Reviews, 49, pp. 736-755, 2015. https://doi.org/https://doi. org/10.1016/j.rser.2015.04.095.

[19] Taleb, H.M., Natural ventilation as energy efficient solution for achieving low-energy houses in Dubai. Energy and Buildings, 99, pp. 284-291, 2015. https://doi.org/https:// doi.org/10.1016/j.enbuild.2015.04.019.

[20] Barbosa, S. \& Ip, K., Predicted thermal acceptance in naturally ventilated office buildings with double skin façades under Brazilian climates. Journal of Building Engineering, 7, pp. 92-102, 2016. https://doi.org/10.1016/j.jobe.2016.05.006

[21] Sotelo-Salas, C., Esparza-López, C.J. \& Escobar-Del Pozo, C., Comportamiento Térmico de fachada ventilada opaca en clima cálido seco extremo. Revista de Arquitectura y Diseño, 3(10), pp. 20-28, 2019. https://doi.org/10.35429/JAD.2019.10.3.20.28

[22] Rubiano, M.A., La fachada ventilada y el confort climático: un instrumento tecnológico para edificaciones de clima cálido en Colombia. Dearq Revista de Arquitectura/Journal of Architecture, 18, pp. 138-145, 2016. https://doi.org/10.18389/dearq18.2016.08

[23] Barbosa, S. \& Ip, K., Perspectives of double skin façades for naturally ventilated buildings: A review. Renewable and Sustainable Energy Reviews, 40, pp. 1019-1029, 2014. https://doi.org/10.1016/j.rser.2014.07.192

[24] Fantucci, S., Marinosci, C., Serra, V. \& Carbonaro, C., Thermal performance assessment of an opaque ventilated façade in the Summer period: Calibration of a simulation model through in-field measurements. Energy Procedia, 111, pp. 619-628, 2017. https://doi.org/10.1016/j.egypro.2017.03.224

[25] Luciani-Mejia, S., Velasco-Gomez, R. \& Hudson, R., Eco-envolventes: Análisis del uso de fachadas ventiladas en clima cálido-húmedo. Revista de Arquitectura, 20(2), pp. 62-77, 2018. https://doi.org/10.14718/revarq.2018.20.2.1726

[26] Charde, M. \& Gupta, R., Design development and thermal performance evaluation of static sunshade and brick cavity wall: An experimental study. Energy and Buildings, 60, pp. 210-216, 2013. doi:10.1016/j.enbuild.2012.12.021

[27] Friess, W.A. \& Rakhshan, K., A review of passive envelope measures for improved building energy efficiency in the UAE. Renewable and Sustainable Energy Reviews, pp. 485-496, 2017. https://doi.org/10.1016/j.rser.2017.01.026

[28] Rizzarello, F., Hongn, M. \& Gea, M., Simulación computacional del comportamiento térmico de una vivienda social en Salta Capital. Energías Renovables y Medio Ambiente, 42, pp. 15-27, 2018.

[29] Roversi, R., Cinquepalmi, F., Cumo, F. \& Pennacchia, E., Experimental envelopes and their integration in the Building Information Modeling energy simulation process. International Journal of Energy Production and Management, 3(2), pp. 97-109, 2018. https://doi.org/10.2495/EQ-V3-N2-97-109 
[30] Arévalo, K., Pastrano, E. \& Armijos, V., Relación beneficio - costo por tratamiento en la producción orgánica de las hortalizas (Cilantro, Lechuga, Cebolla Roja, Cebolla de Rama) en el cantón Santo Domingo de Los Colorados. Revista Publicando, 3(7), pp. 503-528, 2016.

[31] García, E., Modificaciones al sistema de clasificación climática de Koppen, Instituto de Geografía, UNAM, México, 2004.

[32] Servicio Meterológico Nacional, Información climatológica por estado. https://smn. conagua.gob.mx/es/informacion-climatologica-por-estado?estado=bc

[33] EnergyPlus.net. 2021. Weather Data | EnergyPlus. [online] Available at: https://energyplus.net/weather, Accessed 052020.

[34] American Society of Heating, Refrigerating and Air-Conditioning Engineers. ASHRAE Handbook of fundamentals. Atlanta, Ga: American Society of Heating, Refrigerating and Air-Conditioning Engineers, 2017.

[35] Luna, A., Machote_Fanger_2Oct2019. Universidad Autónoma de Baja California, 2019.

[36] International Standard ISO 7730, Ergonomics of the thermal environment - Analytical determination and interpretation of thermal comfort using calculation of the PMV and PPD indices and local thermal comfort criteria, pp. 2, 2005.

[37] Instituto Nacional de Estadística y Geografía, (INEGI). Índice nacional de precios al consumidor, pp. 11, 2020.

[38] Luna, A., COSTO de Energía CFE_2019, Universidad Autónoma de Baja California. 2019.

[39] Baca, G., Evaluación de Proyectos. Administración de SEP, Clases de 10mo. Nivel, Universidad Politécnica Salesiana (UPS), Escuela de Eléctrica, pp. 356, 2013.

[40] Reyes-Barajas, K., Romero-Moreno, R., Sotelo-Salas, C., Luna-León, A. \& BojórquezMorales, G., Passive strategies for energy-efficient building envelopes for housing developments in hot arid climates. WIT Transactions on Ecology and the Environment, Vol. 249, pp. 115-125, 2020. 